\title{
THE EFFECTIVENESS OF RATIONAL EMOTIVE BEHAVIOR THERAPY GROUP COUNSELING IN REDUCING CHEATING BEHAVIORS
}

\section{Ariadi Nugraha*, Sri Hartini \\ *Correspondent Author}

Ariadi Nugraha

Universitas Ahmad Dahlan

Jalan Ring Road Selatan Yogyakarta, Indonesia

Email: ari.nugraha@bk.uad.ac.id

Sri Hartini

Universitas Ahmad Dahlan

Jalan Ring Road Selatan Yogyakarta, Indonesia

Email: sri.hartini@bk.uad.ac.id

Page

84-88

\begin{abstract}
This study aims to reduce cheating behavior in students by using Rational Emotive Behavior Therapy group counseling. This research is a pre-experimental design research, namely One Group Pretest and Posttest Design. The subjects of this study were ten third semester students of the Guidance and Counseling study program at Ahmad Dahlan University, ten students were taken using purpsoive sampling technique. The instrument used in this research is the cheating behavior scale. Analysis of the data used in this study by using the effectiveness test with the t-test formula. The results of the study showed that group counseling with the Rational Emotive Behavior Therapy approach was proven effective in reducing cheating behavior in Guidance and Counseling students at Ahmad Dahlan University. Most of the cheating behavior carried out by students in the category of social passive and cheating behavior in students is mostly based on a lack of confidence in their abilities. The results of this study can be used as an alternative counseling strategy for counselors in universities to reduce cheating behavior in students.
\end{abstract}

Kata kunci : group counseling, cheating, rational emotive behavior terapy.

\section{INTRODUCTION}

Cheating behavior is one of the problems in Indonesian education. One of the cheating phenomena occurred during the 2019 National Examination in 2019. 126 complaints of cheating during the 2019 National Examination were reported. Furthermore, Ministry of Education and Culture reports that cheating case during exam exhibit an increasing trend from 71 and 79 cheater in 2017 and 2018, to 126 cheaters in 2019 (Abdi, 2019).

Cheating behavior can take many forms: writing a cheat sheet on the table or in the palm of the hand, writing on a piece of paper hidden in the folds of a shirt, and looking at a manual or notebook during an exam, among others (Lewellyn \& Rodriguez, 2015). 


\section{5| PSIKOPEDAGOGIA}

JURNAL BIMBINGAN DAN KONSELING

Vol.10, No.2, December 2021

Cheating behavior is cannot be justified, it is a problem that can leads to confusion in measuring students' abilities, among other adverse effects. Cheating behavior blurs the students' ability and mastery as the score can no longer represent one's true ability (Choo \& Tan, 2015; Ding, et al., 2014).

Despite its detrimental effect, cheating is common among adolescents, both school and university level students. This phenomenon occurs because most students focus merely on grade. Adolescents cheat due to pressure to get good grades as a requirement to enter a university or to maintain the average grades they have earned (Eriksson Li \& McGee. T. R, 2014; Khodaie, et al., 2011). Study conducted by Winardi, Mustikarini \& Anggraeni (2017) of 342 students at one university in Indonesia found that $77.5 \%$ of respondents admitted to having committed academic dishonesty by cheating.

The problem of cheating on among adolescents is alarming and requires immediate solution as it threaten the development of honest, confident future generation. Counseling service can serve as one of the alternative strategies to reduce cheating behaviors (Ismail \& Yussof, 2016). One form of effective counseling services for adolescents is group counseling (Jacob, 2009). Group counseling is provided by counselors to several students to help them solve their problems and develop their potenials (Sutanti, 2015). The rational emotive behavior therapy approach is one approach in group counseling services emphasizing togetherness and interaction between rational thinking, emotion, and behavior. This approach believes that significant changes in mindset can result in different thought, feeling, and behaviors (Corey, 2012; Yeager \& Dweck, 2012).

In this regard, counselors at various levels of education need to develop a counseling service to reduce cheating behavior. Therefore, this study attempts to reduce students' cheating behavior using Rational Emotive Behavior Therapy group counseling. The results of this study can be used as an alternative counseling for counselors in university level to reduce students cheating behavior.

\section{RESEARCH METHOD}

This pre-experimental study applied One Group Pretest and Posttest Design by conducting five sessions of REBT group counseling, with 120 minutes each. This study inlvolved ten 3rd-semester students in guidance and counseling department of Ahmad Dahlan University, recruited using purpsoive sampling technique. The data were collected using cheating behavior scale and analyzed using t-test.

\section{RESULT AND DISCUSSION}

The variable of cheating behavior is revealed by using a cheating behavior scale based on the form of cheating behavior according to Hetherington \& Feldman (1964): a) Individual-planned, b) Individualisticopportunistic, c) Social-active, d) Socialpassive. Individual-opportunistic behavior can be interpreted as a behavior where students change an answer when an exam or test is in progress by using notes when the teacher leaves the class. Independent-planned can be identified as using notes when a test or exam takes place, or bringing answers that have been completed or prepared by writing them down before the exam takes place. Socialactive is cheating behavior where students copy or view or ask for answers from others. Social-passive is allowing someone to view or copy the answer.

Based on the results of data analysis before being given group counseling services, it showed that the highest score was 130 while the lowest was 110 . The pretest results also showed that there were two students in the high cheating behavior category, seven students in the moderate cheating behavior category and one student in the cheating behavior category. low. Furthermore, after being given group counseling services using a rational emotive behavior therapy approach, it showed that the highest posttest score was 125 while the lowest was 106 . The posttest results also showed that there were two students in the high cheating behavior category, six students in the moderate 
cheating behavior category and two students in the category of low cheating behavior. The results obtained from the pretest and post-test students' cheating behavior are depicted in figure 1 .

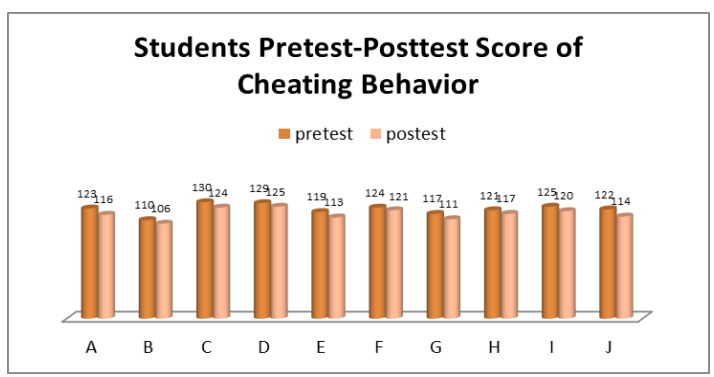

Figure 1

Pretest-Posttest Scores of Students' Cheating Behavior

Furthermore, based on the results of data analysis, it is known that the cheating behavior of Guidance and Counseling students at the University of Ahmad Dahlan in each form of cheating behavior on the pretest score showed the highest in the form of social passive cheating behavior with an average item score of 2.91 and the lowest in the form of individualistic cheating behavior. opportunistic with a mean item score of 2.70 . Meanwhile, the Individual-planned cheating behavior has an average item score of 2.81 and the Social-active cheating behavior has an item average score of 2.88. The posttest score shows that the highest is still in the form of social passive cheating behavior with an average item score of 2.81 and the lowest is still in the form of Individualistic-opportunistic cheating behavior with an average item score of 2.57. Meanwhile, the Individual-planned cheating behavior has a mean item score of 2.71 and the Social-active cheating behavior has an item average score of 2.70. Overall, the average score for each form of cheating behavior decreased. The results obtained from the pretest and posttest of students' cheating behavior in terms of the average items for each form of cheating behavior are depicted in figure 2 .

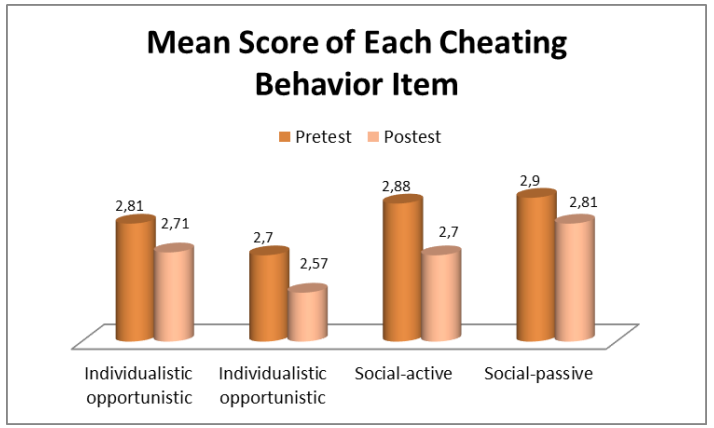

Figure 2

Mean Score of Each Cheating Behavior Item

Furthermore, based on the results of data analysis of hypothesis testing using the t-test formula by comparing scores before and after group counseling services with the REBT approach were given five times with an implementation time of 120 minutes per session, showing the value of $t=2,359$. Then, a test was conducted on the table of values for the $t$ distribution at a significant level of $5 \%$, namely 2.101. This shows that the value of tcount is greater than the value of ttable, namely $2,359>2.101$ or $p=000$ ( $p, 0.05 \%)$, so that there is a difference in cheating behavior before being given services with cheating behavior after being given group counseling services using the Rational Emotive Behavior Therapy approach. The results of this study indicate that there is an effect of group counseling services on reducing cheating behavior in UAD guidance and counseling students.

Based on the study of data through interviews during the counseling service process, it was found that the motivation underlying the cheating behavior of ten students was due to lack of self-confidence and lack of self-efficacy. Subject 1: not confident to be able to answer and the questions in the exam are not the same as the material given during lectures. Subject 2: wants to get good grades but who doesn't have to rack his brain and is not sure what he answered during the exam. Subject 3: hesitant and not confident about what is produced other than that during the exam is lazy to record or summarize the material given by the lecturer. Subject 4: lazy to study, doubtful about the answer itself, sometimes 


\section{7| PSIKOPEDAGOGIA}

JURNAL BIMBINGAN DAN KONSELING

Vol.10, No.2, December 2021

the exam questions are difficult to understand and have the desire to get out of the exam room quickly. Subject 5: unsure of their own results, supervisors who are supervising exams are easy to cheat and lazy to study. Subject 6: difficulty concentrating in studying and feeling unable to answer on their own. Subject 7: has little value but wants to make parents happy. Subject 8: lack of selfconfidence, lazy to study and nervous in doing something but wants to get high marks than his friends. Subject 9 hesitated in answering. Subject 10: believes that a friend's answer is better and correct than him, lacks confidence and is lazy to study.

In this study, it was revealed that group counseling with a rational emotive behavior therapy approach was proven to be effective in reducing cheating behavior in students. This is in line with the study conducted by Wijayanti, Sugiharto, Wibowo (2018) that rational emotive behavior therapy counseling has been proven effective in reducing cheating behavior. In line with the study of Hartanto (2011) and Hartono (2018) that counseling with a rational emotive behavior therapy approach has been proven to be effective in reducing cheating behavior. The novelty of this study is that rational emotive behavior therapy counseling in this study is given in a group counseling format for students.

In addition, other findings in this study indicate that most of the cheating behavior carried out by guidance and counseling students at Ahmad Dahlan University is in the highest category of social passive, then social active. Social-passive is allowing someone to view or copy the answer. Social-active is cheating behavior where students copy or view or ask for answers from others. This study is in line with the results of a study conducted by Boyle \& Carpenter (2016) that dishonesty in the form of cheating in universities is mostly done due to social opportunities and a supportive environment such as supervisory carelessness and opportunities such as allowing someone to see or copy the answers. Opportunities and social pressures can encourage students to cheat on exams (Lewellyn \& Rodriguez, 2015; Day, et al.,2011).

This study also found that some students expressed fear of failure and fear of losing to friends to be one of the factors that influence someone to cheat. This is in line with the findings of research conducted by lfeagwazi, Chukwuorji, Egbodo, \& Nwoke (2019) that peer pressure and fear of failure are the most common factors influencing cheating behavior by college students. The results of this study also show that the underlying cheating behavior carried out by the students is due to a lack of self-confidence and belief in selfefficacy. In line with research conducted by Fadillah (2019), it shows that many students' cheating behavior comes from low selfconfidence.

\section{CONCLUSION}

This study showed that REBT group counseling was effective in reducing students' cheating behavior. The socialpassive category was found to be the highest aspect of cheating behavior among guidance and counseling department students. This study found that students' confidence in their ability significantly affect the cheating behavior. The result of this study can be used as an alternative counseling strategy for university counselors to reduce students cheating behavior.

\section{REFERENCES}

Abdi, Alfian Putra. (2019). Kemendikbud Catat 126 Kecurangan Selama Ujian Nasional 2019. Https://Tirto.Id/Kemendikbud-Catat126-Kecurangan-Selama-UjianNasional-2019-Drnd. Diakses 4 Januari 2020 Pukul 10.15 WIB.

Boyle, D. M., Boyle, J. F., \& Carpenter, B. W. (2016). Accounting Student Academic Dishonesty: What Accounting Faculty And Administrators Believe. The Accounting Educator's Journal. Special Edition, 39-61.

Choo, F., \& Tan, K. (2015). The Effect Of Fraud Triangle Factors On Students' Cheating Behaviors. Advances In Accounting Education, 205-220. 
Corey, Gerald. (2012). Theory And Practice Of Group Counseling.Eighth Edition. USA: Broks/Cole Thompson.

Day, N. E., Hudson, D., Dobies, P. R., \& Waris, R. (2011). Student Or Situation? Personality And Classroom Context As Predictors Of Attitudes About Business School Cheating. Social Psychology Of Education, 14(2), 261-282.

Ding, X. P., Omrin, D. S., Evans, A. D., Fu, G., Chen, G., \& Lee, K. (2014). Elementary School Children's Cheating Behavior And Its Cognitive Correlates. Journal Of Experimental Child Psychology, 121, 85-95.

Eriksson Li \& Mcgee. T. R (2014). Cheating On Examinations And its Predictors Among Undergraduate Students At Hawassa University College Of Medicine And Health Science, Hawassa, Ethiopia. BMC Medical Education 14 (1): 89.

Fadillah, Andrie. (2019). Hubungan Antara Efikasi Diri Dengan Perilaku Menyontek Pada Mahasiswa. Psikoborneo, 7(4), 657-664.

Hartanto, D. (2011). Penggunaan REBT Untuk Mereduksi Perilakui Mencontek Pada Siswa Sekolah Menengah. Contemporary And Creative Counseling Techniques: How To Improve Your Counceling Skills And To $\mathrm{Be}$ More Creative In Counceling Sessions. Pp. 66-75.

Hartono. (2018). Keefektifan Konseling Rational Emotive Behavior Untuk Mereduksi Perilaku Menyontek Siswa SMA. Perspektif IImu Pendidikan, 32(2), 117-126.

Hetherington, E. M., \& Feldman, S. E. (1964). College Cheating As A Function Of Subject And Situational Variables. Journal Of Educational Psychology, 55(4), 212.

Ifeagwazi, C. M., Chukwuorji, J. C., Egbodo, S. O., \& Nwoke, M. B. (2019). Peer Pressure, Fear Of Failure And Examination Cheating Behaviour In The University: Does Gender Make The Difference?. Cognition, Brain, Behaviour, 23(1), 43-62.

Ismail, S. And Yussof, S. H., (2016). Accounting Research Journal Cheating Behaviour Among Accounting Students: Some Malaysian Evidence. Accounting Research Journal Iss Accounting Research Journal, 29(1), 20-33.
Jacob, Ed. (2009). Group Counseling Strategies And Skill. Fiveth Edition. USA: Broks/Cole Thompson.

Khodaie, E., Moghadamzadeh, A., \& Salehi, K. (2011). Factors Affecting The Probability Of Academic Cheating School Students In Tehran. ProcediaSocial And Behavioral Sciences, 29, 1587-1595.

Lewellyn, P. G, \& Rodriguez, L.C. (2015). Does Academic Dishonesty Relate To Fraud Theory? A Comparative Analysis. American International Journal Of Contemporary Research, 5(3), $1-6$.

Sutanti, Tri. (2015) . Pelaksanaan Layanan Konseling Kelompok Pada Siswa Cerdas Istimewa Di SMA Negeri Kota Yogyakarta. Jurnal Konseling Gusjigang, 1(1).

Wijayanti, Arni, Dwi Yuwono Puji Sugiharto \& Mungin Eddy Wibowo. (2018). The Effectiveness Of Rational Emotive Behavior Therapy (REBT) Group Counseling To Reduce Cheating Behavior. Jurnal Bimbingan Dan Konseling, 8(2).

Winardi, R. D., Mustikarini, A., \& Anggraeni, M. A (2017). Academic Dishonesty Among Accounting Students: Some Indonesian Evidence. Jurnal Akuntansi Dan Keuangan Indonesia, 14(2), 142164.

Yeager, D. S., \& Dweck, C. S. (2012). Mindsets That Promote Resilience: When Students Believe That Personal Characteristics Can Be Developed. Educational Psychologist, 47(4), 302-314. 